\title{
Study on Chinese Listed Commercial Banks Business Innovation Ability Evaluation
}

\author{
Xinming Feng ${ }^{1, a}$, Dongdong Wang ${ }^{2, b}$ \\ ${ }^{1,2}$ College of Economics and Management, Jiangsu University of Science and Technology, Jiangsu \\ Zhenjiang, China \\ a664699282@qq.com, \\ bsongruyi2544@163.com
}

Keywords: Commercial bank; Innovation ability; Bank business; Principal component analysis.

\begin{abstract}
In this paper, we identify business innovation ability of these banks through the use of empirical data collected from 16 listed Chinese commercial banks from 2010 to 2014. We find the different weight factors that influence business innovation ability by SPSS. Further, we evaluate the business innovation ability of these banks by using these different indexes. The data was collected from annual financial report and wind database. The empirical data showed the intermediary business innovation is the most important influence factors of listed commercial banks. In addition, the asset business innovation capability is the second important influence factor; the debt business is relatively less relevant. Thus, listed commercial banks could improve their business innovation ability by developing the new intermediary business, improving the level of intermediary business services and broadening the scope of intermediary business model.
\end{abstract}

\section{Introduction}

Business innovation capability of commercial banks is the core of banks' capability to innovate, business activities are the basic units of the material basis that necessary for the survival and development of enterprises, which is the most important part of their daily activities.

And business innovation capability is the objective selection path that is essential for enterprises to seek development. Faced with the accelerated pace of interest rate marketization, continued rise of banks' cost of debt and the rise of Internet finance, Yu'ebao as the representative of Money Market Fund diverts savings deposits of commercial banks, P2P network as the representative of online borrowing and lending affects loan business of commercial banks, diluting the funding needs of commercial banks' potential customers. Financial product yields of third-party financial platform soars, therefore banking financial services faces severe attacks, large financial data can accurately target their customers' financial needs and credit analysis by cloud computing and other advanced methods, lower business costs and more competitive advantage. The above Internet finance are in different forms of their own characteristics, showing great vitality and impact, commercial banks which take interest margin as the main profitable business model are unsustainable, operating homogenization of the major commercial banks is quite serious, seriously affects the competitiveness of commercial banks, and meanwhile commercial banks' business face enormous challenges, how to promote the business innovation capability of commercial banks now become the priority.

\section{Research Review}

Domestic and foreign scholars give relevant definitions on innovation capability, of which the most famous definition is Penrose who has put forward the "outstanding capability" concept, defined it as "enterprises to better plan and make use of resources to obtain the economic rent" . This is basis for quantitative innovation indicators by most scholars _ based on relevant indicators of economic value to measure innovation capability of enterprises. Van Horne (1985) [1]believes that financial innovation capability can be a new product or process, and this innovation is usually improvements on 
existing products or processes, to make the market more complete and active.From the existing practice of financial innovation point of view, the probability to produce a completely innovative new product is indeed very low, so innovation capability can be defined as the breakthrough and improvement of the present situation. This definition breaks the traditional concept of innovation, so that optimizing and improving also counts as innovative range.Alam[2]believes that financial innovation capability can be summarized in three aspects: innovation of information capability, innovation of products and services, and innovation of risk control. The researcher mainly summed up financial innovation capability as three important fundamental aspects, which has a strong one-sidedness, it is difficult to fully reflect the innovation capability of commercial banks, and the definition only stops at the macro level. Mingxin Zhu（2013）[3]and Yingying Zhu (2011) [4]take the intermediate business income as a measure of the intermediate variables of commercial banks' innovation capability in the measurement of innovation capability of listed banks. With single index measure of innovation capability lack of scientific nature, we need to build a comprehensive innovation capability evaluation index system of commercialbanks.

Above all, the index system of commercial banks' innovation capacity is still not mature, some indicators are difficult to quantify, and the study on a specific category of innovation is not in depth. This paper will mainly focus on innovation capability of commercial banks from the business perspective, and build innovation capacity evaluation system from assets business end, liabilities business end, intermediate business end as well as the supporting business end.

Based on the previous definitions of innovation, this paper will define the innovation capability of commercial banks as commercial banks' ability to use existing resources to improve the situation of their real business.

\section{Study Design}

\section{Indicator Variable selection}

Combining the four main business units of commercial banks, select loan growth and personal loans ratio in the assets business as main indicators measuring assets business innovation capability. Select interbank deposit growth and proportion of demand depositsas the main indicators measuring liabilities business innovation capability. Select non-interest income ratio and intermediate business income ratio as main indicators measuring intermediate business innovation capacity. Select the undergraduate academic and above staff ratio and per capita share of assets as indicators of a measurement of supporting business innovation capacity. Based on the above index system to measure the business innovation capability of commercial banks.

Table1 Definition of business innovation capacity indicators

\begin{tabular}{|c|c|c|c|}
\hline Meaning of variables & Variable index & Symbol & Definition \\
\hline \multirow{2}{*}{$\begin{array}{l}\text { Assetsbusiness } \\
\text { innovation capacity }\end{array}$} & Corporate loan growth & $\mathrm{X}_{1}$ & $\begin{array}{c}\text { Amount of changes in corporate loans/total } \\
\text { loans at the end of last year } * 100 \%\end{array}$ \\
\hline & Personal loans ratio & $\mathrm{X}_{2}$ & $\begin{array}{l}\text { Amount of personal loans / year-endtotal loans } \\
\qquad 100 \%\end{array}$ \\
\hline \multirow{2}{*}{$\begin{array}{l}\text { Liability business } \\
\text { innovation capacity }\end{array}$} & $\begin{array}{l}\text { Proportion of demand } \\
\text { deposits }\end{array}$ & $\mathrm{X}_{3}$ & $\begin{array}{l}\text { The balance of demand deposits / year-end } \\
\text { balance of deposits * 100\% }\end{array}$ \\
\hline & $\begin{array}{l}\text { interbank deposit } \\
\text { growth }\end{array}$ & $\mathrm{X}_{4}$ & $\begin{array}{c}\text { Amount of changes in interbank deposits /year } \\
\text { beginning interbank deposit balance * } 100 \%\end{array}$ \\
\hline \multirow{2}{*}{$\begin{array}{l}\text { Intermediate business } \\
\text { innovation capacity }\end{array}$} & $\begin{array}{l}\text { Non-interest income } \\
\text { ratio }\end{array}$ & $\mathrm{X}_{5}$ & Non-interest income/operating income $* 100 \%$ \\
\hline & $\begin{array}{l}\text { Intermediate business } \\
\text { income ratio }\end{array}$ & $\mathrm{X}_{6}$ & $\begin{array}{l}\text { Intermediate business income/operating income } \\
\qquad * 100 \%\end{array}$ \\
\hline \multirow{2}{*}{$\begin{array}{l}\text { Supporting business } \\
\text { innovation capacity }\end{array}$} & $\begin{array}{c}\text { Undergraduate } \\
\text { academic and above } \\
\text { staff ratio }\end{array}$ & $\mathrm{X}_{7}$ & $\begin{array}{l}\text { Number of undergraduate academic and above } \\
\text { staff/total number of employees of the Bank } \\
\qquad * 100 \%\end{array}$ \\
\hline & Assets per capita & $\mathrm{X}_{8}$ & $\begin{array}{l}\text { Year-end total assets of the Bank/total number } \\
\text { of employees of the Bank *100\% }\end{array}$ \\
\hline
\end{tabular}




\section{Research samples}

Research samples of this paper comes from China's 16 listed commercial banks listed on the Shanghai and Shenzhen stock markets, whose Panel data mainly uses annual data (2010-2014) of the financial reports and China Banking Association, China Banking Regulatory Commission and other authoritative regulatory organizations and the wind database.

\section{Basic Mathematical Models}

Using Panel data and indicators to measure the business innovation capability of commercial banks in China, more metrics, larger dimensions, needs to rationally determine the weight of each index in the evaluation, to achieve the purpose of comprehensive evaluation, so we will use the principal component analysis model.

Let $\mathrm{X}=\left(X_{1} \cdots X_{P}\right)^{\prime}$ be a $\mathrm{p}$-dimensional random vector, mean value $\mathrm{E}(X)=\mu$ covariance $D(X)=\Sigma$, use p vectors in $X$ (ie $\mathrm{p}$ indicator vectors) to do a linear combination (ie comprehensive index vector) : $\left(\begin{array}{l}F_{1} \\ F_{2} \\ \vdots \\ F_{p}\end{array}\right)=\left(\begin{array}{ccc}a_{11} & \ldots & a_{p 1} \\ \vdots & \ddots & \vdots \\ a_{1 p} & \cdots & a_{p p}\end{array}\right)\left(\begin{array}{l}X_{1} \\ X_{2} \\ \vdots \\ X_{p}\end{array}\right)$

Requirements of the above matrix equation:

(1) $a_{1 i}{ }^{2}+a_{2 i}{ }^{2}+\cdots+a_{p i}{ }^{2}=1, \quad i=1, \cdots p$

(2)Fi and $\mathrm{Fj}(\mathrm{i} \neq \mathrm{j}, \mathrm{j}=1, \ldots \mathrm{P})$ are not relevant ;

(3) $\mathrm{Fi}$ is the largest variance among all the linear combination with $X_{1} \cdots X_{P}, F_{2}$ is the largest variance among all the linear combination with $X_{1} \cdots X_{P}$ that is not relevant with $F_{1}, F_{\mathrm{p}}$ is the largest variance among all the linear combination with $X_{1} \cdots X_{P}$ that is not relevant with $F_{1} \cdots F_{\mathrm{p}-1}$.

Select characteristic equation of variable observation matrix through solution , get p eigenvalues and eigenvectors, eigenvalues follow the order from smallest to largest, on behalf of the variance of the observed variables, and principal component is a linear combination of the corresponding eigenvectors. Generally select the cumulative variance whose contribution rate is greater than $85 \%$, can fully reflect information of the selected index, each contribution rate corresponding to the principal component is weighted sum to get a comprehensive evaluation results of innovation capability.

\section{Empirical Analysis}

According to the previously selected Index of commercial banks' business innovation capability, by collation, analysis and calculation of 16 listed commercial banks' related indicators data, and for indicators of the undergraduate academic and above staff ratio, we adopt mean value method of time series as processing methods for Huaxia Bank, China Minsheng Bank, Agricultural Bank of China and China Merchants Bank who have index missing values in partial years. This method can reduce the influence of errors to the maximum extent. Input variables of related indicators using SPSS19.0, and then make associated verification and analysis.

\section{Model checking}

Using the above raw data for statistical tests to determine whether the original index data is suitable for factor analysis. On the basis of standardization after entering the raw data, to calculate the correlation coefficient matrix and statistical test. Test results obtained in the following table.

From the output value of the statistical verification results, we can see that KMO statistic value $0.685>0.5$, Bartlett's test of sphericity chi-square statistic Sig value $0.000<0.01$. It can be concluded that the selected indicators in this paper can be applied to the principal component analysis, extremely 
significant difference exists among the raw data variables, there is a certain space for dimension reduction, therefore can better apply method of factor analysis to study the issue.

\section{Extracting main ingredients}

This paper extracts factors according to the eigenvalue greater than 0.5 , and to ensure that their cumulative variance contribution rate is greater than $85 \%$, thus to select the main components, so as to keep the data information to the greatest extent, to describe business innovation capability. According to the output results of statistical software (table below), and based on the data output of the total variance explained table, determine the number of principal components for 5 , by these 5 principal components can be summarized better to reflect the business innovation capability of commercial banks.

\section{Principal component rotation}

By rotating the main component of the matrix, a greater degree of highlighting the differences between the major components of the main internal factor indicators, more obvious highlighting the major role in some of the indicators in this component, and reflecting the reality of the connotation of the main components of the performance. In this paper, orthogonal rotation method for rotating the main ingredient matrix is used.

\section{Positive Results}

From the data analysis of the rotating components associated payload data, in the first principal component $\mathrm{F}_{1}, \mathrm{X}_{2}, \mathrm{X}_{5}, \mathrm{X}_{6}$ load factor is relatively large, and therefore $\mathrm{F} 1$ can be interpreted as a major component intermediate business innovation business innovation capacity and assets, since the main components of the business affected by the double intermediate indicators can be seen as a priority intermediate business innovation main ingredient. In the second main component $F_{2}, X_{7}, X_{8} S$ load factor is relatively large, and therefore can be used as the main component F2 interpreted to support business innovation main component. In the third main component of the $X_{1} F_{3}$ load factor is relatively large, so the $\mathrm{F}_{3}$ can be interpreted as an asset business innovation main component. In the fourth main component in $\mathrm{F}_{4}, \mathrm{X}_{4}$ greatest impact can be interpreted as a main component of liabilities business innovation. In the fifth principal component $\mathrm{F} 5$, the greatest impact of $\mathrm{X}_{3}$, can be interpreted as the main component of liabilities business innovation.

$$
\begin{aligned}
\mathrm{F}_{1} & =-0.201 \mathrm{X}_{1}+0.919 \mathrm{X}_{2}-0.075 \mathrm{X}_{3}-0.145 \mathrm{X}_{4}+0.850 \mathrm{X}_{5}+0.872 \mathrm{X}_{6}-0.040 \mathrm{X}_{7}-0.345 \mathrm{X}_{8} \\
\mathrm{~F}_{2} & =0.029 \mathrm{X}_{1}+0.054 \mathrm{X}_{2}-0.235 \mathrm{X}_{3}+0.120 \mathrm{X}_{4}-0.242 \mathrm{X}_{5}-0.251 \mathrm{X}_{6}+0.939 \mathrm{X}_{7}+0.707 \mathrm{X}_{8} \\
\mathrm{~F}_{3} & =0.971 \mathrm{X}_{1}+0.019 \mathrm{X}_{2}-0.016 \mathrm{X}_{3}+0.020 \mathrm{X}_{4}-0.219 \mathrm{X}_{5}-0.232 \mathrm{X}_{6}+0.027 \mathrm{X}_{7}-0.030 \mathrm{X}_{8}
\end{aligned}
$$

$$
\mathrm{F}_{4}=0.018 \mathrm{X}_{1}-0.007 \mathrm{X}_{2}+0.002 \mathrm{X}_{3}+0.980 \mathrm{X}_{4}-0.134 \mathrm{X}_{5}-0.164 \mathrm{X}_{6}+0.060 \mathrm{X}_{7}+0.141 \mathrm{X}_{8}
$$

$$
F_{5}=-0.019 X_{1}+0.039 X_{2}+0.953 X_{3}-0.005 X_{4}-0.050 X_{5}-0.097 X_{6}-0.099 X_{7}-0.311 X_{8}
$$

The contribution ratio of the total variance explained in the table calculated five comprehensive factor variance can be the common factor of five scores weighted average sum, the weights whichever variance contribution rate as weights, the main component of the rotation after five contribution rate variance matrix were $40.123 \%, 20.260 \%, 11.598 \%, 10.216 \%, 7.795 \%$. Thus, the total commercial banking innovation capability evaluation expression can be expressed as:

$\mathrm{F}=40.123 \% \mathrm{~F}_{1}+20.260 \% \mathrm{~F}_{2}+11.598 \% \mathrm{~F}_{3}+10.216 \% \mathrm{~F}_{4}+7.795 \% \mathrm{~F}_{5}$

According to the above arithmetic expressions, you can calculate the major listed commercial banks, the main component score and business innovation comprehensive evaluation score, in order to evaluate the business innovation of the listed commercial banking. 
Table2 Chinese 16 listed commercial Banks business innovation ability evaluation scores and rankings

\begin{tabular}{c|c|c|c|c|c|c|c}
\hline Name & FAC1_1 & FAC2_1 & FAC3_1 & FAC4_1 & FAC5_1 & Score & Ranking \\
\hline CMB & 2.30864 & 1.40537 & -0.2333 & 0.13676 & 1.09478 & 1.28328 & 1 \\
CMBC & 2.41927 & -0.18362 & 1.04854 & 0.61707 & -1.47293 & 1.00332 & 2 \\
CEB & 1.58875 & 0.92003 & -0.75634 & -0.2277 & -1.20782 & 0.61872 & 3 \\
CIB & 0.70981 & 1.55173 & 0.3117 & -0.37193 & -0.44165 & 0.56291 & 4 \\
BONB & 0.57218 & 1.86127 & -0.17378 & -0.77622 & 0.1949 & 0.52241 & 5 \\
PAB & 1.6804 & -0.9877 & 1.48738 & -0.46574 & -2.76404 & 0.38359 & 6 \\
CCB & 0.59417 & 1.39381 & -0.96793 & -0.37867 & -0.57755 & 0.32482 & 7 \\
BOC & 0.99458 & -0.26493 & -0.65056 & -0.24004 & -0.4416 & 0.21099 & 8 \\
CCB & 0.7961 & -0.55461 & -0.94841 & 0.36759 & 0.48201 & 0.17218 & 9 \\
BCM & 0.13105 & 0.59018 & -1.90943 & -0.05339 & 0.61658 & -0.0067 & 10 \\
BOB & -0.74275 & 1.89466 & -0.78963 & -0.86254 & 0.03581 & -0.09106 & 11 \\
SPDB & -0.04978 & 0.80036 & -0.40041 & -0.67945 & -1.59317 & -0.09786 & 12 \\
ICBC & 0.49119 & -1.23218 & -0.86854 & 0.09486 & -0.0408 & -0.14678 & 13 \\
ABC & 0.04267 & -1.58349 & -0.50334 & -0.08777 & 0.742 & -0.3132 & 14 \\
BON & -0.82354 & 0.98817 & -0.03056 & -1.11693 & -1.04675 & -0.32947 & 15 \\
HXB & -0.96135 & -0.40646 & -0.6142 & -0.71361 & -1.26486 & -0.7108 & 16 \\
\hline
\end{tabular}

Judging from the total score, they are the top-ranked joint-stock banks, joint-stock banks due to strong intermediate business innovation capability. Compared with the state-owned commercial banks, joint-stock banks due to the small market share, competitive pressure and other objective factors, Forced joint-stock banks continue to enhance innovation capability, embodied in the middle of this piece of business. As it can be seen from the first principal component, in the middle of business innovation scores, joint-stock banks was significantly higher than the state-owned commercial banks. And state-owned banks have high credit, compared to wide distribution network, joint-stock banks have a natural disadvantage in liability business, the main ingredient in the fourth and fifth principal component can be seen, except for a few joint-stock banks, state-owned commercial banks liability business innovation capacity score higher ranking than the front. In terms of business innovation support, joint-stock banks since the overall quality of staff is high, high operational efficiency management, support business innovation is also significantly higher than the state-owned commercial banks. Asset business innovation principal components, the advantages of state-owned commercial banks and not a very good show, but the joint-stock banks in corporate lending growth above far more than the state-owned commercial banks, the share of personal loans are matched.

\section{Conclusions}

This paper constructs commercial innovation ability index system of listed banking business, and the main use of principal component analysis, empirical analysis of the main factors of commercial banking innovation capacity market, influence weight sequential order are intermediate business innovation, business assets innovation, support business innovation and liabilities of business innovation. The empirical results show, listed commercial banking business innovation capacity is mainly influenced intermediate business innovation capability, enhance the commercial banking business innovation can be achieved through measures to achieve intermediate innovation capacity. This is also the business of commercial banks at this stage focus on the development of consistent, intermediary business has flexibility and variety of binding and other characteristics, mainly operates through commercial bank credit, which determines the commercial bank may be space for innovation large, truly become a measure of commercial bank business innovation a top priority. In addition, the listed commercial bank assets business are also important factors listed commercial banking business innovation impact. In the major business innovation, and business innovation debt relatively small, which is also the reality of the situation is more consistent, due to regulatory constraints Law on 
Commercial Banks, way less its liabilities, less able to innovate space, respectively in a measure of business innovation in the share component is relatively small.

\section{Suggestions}

a) Develop banking intermediary business, intermediate business channel widening

In the four basic operations of commercial banks among the biggest potential for development of intermediary business, is also the most growth prospects of the business, and in the empirical results can also be found in the middle of the business contribution to the listed commercial banks business innovation rate maximum. In the financial wave of the Internet, the commercial banks to achieve sustainable development, we must vigorously broaden the intermediary business, intermediate rich business types. At the same time, vigorously develop intermediary business is also important to choose cost savings strategy, the cost of doing business in the middle of the four is the lowest in the business, assets business requires a lot of front-line business marketing personnel, liability business may face financial impact of the Internet and the source of compressed liabilities range of support services in personnel costs continue to rise. In the middle of the business development process, the development of space was undoubtedly the most wealth management, guarantee commitments class, investment banking adviser and other new class, and middle class hosting services. Under the new conditions of the industry regulator, innovation of new space in the middle of the business get to see greatly improved, such as the middle class wealth management business, according to the December 20144 CBRC issued a "commercial bank financial services supervision and management approach (draft ) "relaxed kind of financial products, so that commercial banks will not pull through high-yield deposits, to the net type, lower yields of financial products and structured product development direction guide, return to the" Valet "intermediate nature of business finance.

Intermediate business income growth and intermediate business income accounted contrarian, but also bank earnings restructuring importance of good posture and business development in the banking industry faces a bottleneck situation, banks intermediate business is an important breakthrough transformation and upgrading, It enables the rapid development of the banking business, to maintain their competitive advantage.

b) To accelerate the commercial bank "Internet +"

Faced with the "Internet +" the rise of the commercial banks should also be taking advantage of on the Internet to seize the strategic high ground of financial development. While traditional commercial banking and Internet banking is a complementary relationship, the financial impact of the Internet for commercial banks is also very limited. However, the development of Internet technology does a better use of the commercial banks, commercial banks use Internet technology to better diversify liabilities channels to help broaden the sources of funds, liabilities of commercial banks to enhance business innovation. Also, it can reduce the cost of commercial bank human resources, improve the ability to support business innovation and accelerate the commercial bank "asset light" transformation. Develop "Internet +" can effectively monitor the status of the business assets, to grasp the use of flow loans. At the same time, the use of Internet technology can achieve interoperability of information and strengthen cooperation between the commercial banks can improve efficiency in the use of funds, to prevent a surplus lending industry to form a "unwieldy" situation, improve asset business innovation.

Accelerate the commercial bank "Internet +" process, can be "three birds with one stone", so that the assets of the business, supporting business would be enhanced and liabilities of business innovation, enhance the overall commercial banking innovation.

\section{References}

[1] Van Home J.C.1985,"Of Financial Innovations and Excesses", Journal of Finance, 40(3), pp. 620-631. 
[2] Alam I. Innovation strategy process and performance in the commercial banking industry [J]. Journal of Marketing Management, 2003， 19 (9-10):973-999.

[3] Mingxin Zhu.The Empirical Analysis of the Influence of Commercial Banks Innovative Capabilityon Bank Performance [J].Shandong college of Finance academic journal,2013,06:25-32.

[4] Yingying Zhu,Ping Li,Yong Zeng,Jia He. Foreign Strategic Investors and the Innovation Capacity of Domestic Banks: Evidence from 73 Commercial Banks [J].Investment Research,2011,07:55-66.

[5] Yusif Baba. Adopting a specific innovation type versus composition of different innovation types: Case study of a Ghanaian bank [J]. International Journal of Bank Marketing, 2012,303.

[6] Anthony Adu-Asare Idun,Anthony Q.Q. Aboagye. Bank competition, financial innovations and economic growth in Ghana [J]. African Journal of Economic and Management Studies,2014,51. 